\title{
ASSESSMENT FEEDING PACKAGES BASED ON WATER EFFICIENCY FOR DAIRY BUFFALO FARMS UNDER THE MIXED (CROP/LIVESTOCK) FARMING SYSTEM IN EGYPT
}

\author{
M.A.I. Khalil; Amal S. Omar and R.E. Hamouda \\ Animal Production Research Institute, Agricultural Research Center, Ministry of Agriculture and \\ Land Reclamation, Dokki, Giza, Egypt.
}

\section{SUMMARY}

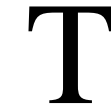
he objective of this study was to quantify water efficiency of dairy buffaloes using one of the animal feeding packages. Hundred fifty farms were selected by using stratified sampling in three governorates Kafr El-Sheikh, Qena and El-Beheira (fifty per each). The questionnaire was designed and pre tested on limiting groups of farms in the three studied areas. Data were collected through farmer's interview to find out buffaloes feeding patterns in winter and summer periods under mixed farming system. Average milk yield/season was calculated from farms data. Six rations were found, two traditional rations (winter and summer) without feeding packages were compared to four rations which including one of the following feeding packages corn silage, berseem hay, urea/ammonia treated straw, and molasses addition. The results showed that average milk yield, water used for crops production (cash/green forage) and water efficiency were 785.861016 and 3.47with traditional ration versus $1094.54,740.67$ and 6.62 with corn silage as feeding package, respectively. Average milk yield, water consumption and water efficiency were 498.3, $543.8,605.8$ and $560.4 \mathrm{~kg}, 1073,1167,1199$ and $1505 \mathrm{~m} 3 / \mathrm{animal} /$ period, 2.40, 2.30, 2.50 and 1.80 L.E/m3 for traditional, berseem hay, treated straw, molasses rations in summer, respectively. In conclusion average milk production has been improved by using feeding packages in ration compared to traditional ration either in winter or summer.

Keywords: Water efficiency, dairy buffaloes, mixed farming systems and corn silage.

\section{INTRODUCTION}

Although water is a renewable natural resource, it has become insufficient at the global level. Unless the current efficiency level of water use can be increased, the trend of water shortages will become more serious. Among agricultural activities, livestock production is mostly considered an intensive water consuming operation although the knowledge and information related to livestock-water interaction appears to be limited in scope (Mengistu et al., 2012). Livestock production has a prominent position in satisfying the diverse needs of humans ranging from the provision of natural animal food products (highly nutritious) to rendering the associated benefits of economic, social, cultural and ecological domains (Thornton et al., 2002).

Animals obtain their water not only from drinking but also from their feed, metabolic processes within the animal and other sources. While access to adequate water is essential for livestock production, drinking water is only of minor significance $(50 \mathrm{~L} /$ day for a Tropical Livestock Unit (TLU) in terms of livestock water budgets in a farming system or watershed as compared to the amount of water depleted for feed production, which can reach 5,000 L/day for a TLU or 100 times that amount directly consumed (Peden et al., 2003). Nonetheless, the daily drinking water requirement of livestock and its regular provision should not be neglected. The metabolic function of water in the animal body is a highly determinant factor for maintaining the normal physiological process and healthy production state of the animal despite its small proportional amount. Water scarcity is a major factor limiting food production. Improving dairy buffalo water efficiency is one of the approaches to address such limitation. Dairy buffalo water efficiency was defined as the ratio of dairy buffalo outputs and services to water depleted in their production. Increasing dairy buffalo water efficiency can help achieve more production per unit of depleted water. In view of Egypt's fixed share from the Nile River and the increase of non-agricultural water uses, the amount of water allocated to agriculture needs to be rationalized by other mean for 


\section{Khalil et al.}

instance return on irrigation water must be maximized. Recent discussion on water efficiency (WE) in agriculture highlights livestock as a key area for WE improvement (Molden, 2007). About 98\% of the water footprint of animal products relates to water use for feed (Mekonnen and Hoekstra, 2010).

Therefore the Study objectives are:

1. To quantify water efficiency in dairy buffaloes by using different feeding packages in the rations versus rations without package.

2. Identify promising strategies and technological interventions to reduce feed water consumption through improving feed quality and choosing appropriate feed package for dairy baffuloes.

\section{MATRIALS AND METHODS}

This study was conducted in three governorates Kafr El-Sheikh, Qena and EL-Beheira. These governorates were purposively selected for the present study mainly because of the fact that they were the forefront governorates in water consumption for land irrigation. A random sampling technique was adopted in selecting 50 household from each governorate to make up a sample size of 150 farmers. The farmers were identified as those who raise milking buffaloes under mixed farming system. The data was collected on April 2015, by means of well structured questionnaire. The detailed questionnaire for collecting baseline data on mixed farming system (crop/dairy buffaloes) included information about herd size, milk production, feed packages and water consumption. Questionnaires were designed and pretested for clarity on limited numbers of farmers who have good experience in rearing buffaloes with or without cow presence under mixed farming system. Trained livestock extension officers in the studied areas were responsible for data collection under supervision of the research team. This study was focused only on farmers who give feeding packages for their animals all over the year, the packages involve the use of Green forage conservation (corn silage or berseem hay), treated roughages with urea or ammonia, and molasses addition. Feedstuffs converted into original crops then water required for irrigation of these crops was calculated for each feeding area per season.

The water needed to produce feed was calculated as follows:

\section{Green forages:}

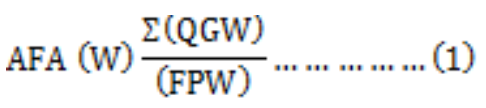

$\mathrm{WWC}=\mathrm{AFA}(\mathrm{W}) * \mathrm{IW}$

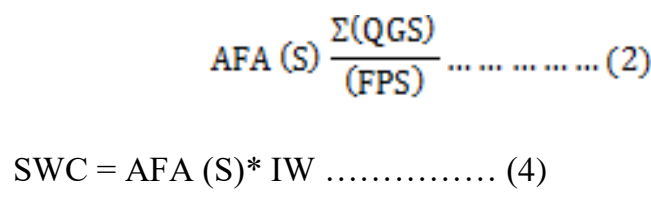

Where:

AFA $(W)$ and $(\mathrm{S})=$ Total areas in feddan of green forages fed to animal in winter and summer, $\Sigma$ QG $(\mathrm{W})$ and $(\mathrm{S})=$ Sum quantities of green forages fed to animal in winter and summer, FPW and FPS = Feddan production of green forage in winter and in summer, WWC and SWC =Total water consumption to the animal from green forages in winter and in summer, IW = Irrigation water required for one feddan of green forage in winter and summer,

\section{Concentrate feeds mixture:}

$\mathrm{WCF}=\Sigma(\mathrm{I} / \mathrm{FP})^{*} \mathrm{IW}$

Where:

$\mathrm{WCF}=$ Irrigation water from concentrates feed mixture ingredients/ animals, $\Sigma(\mathrm{I} / \mathrm{FP}) * \mathrm{IW}=\mathrm{Sum}$ of quantity of each ingredient/ Feddan productivity of this Ingredient $*$ irrigation water required to produce this ingredient.

\section{Roughages:}

Water required to irrigate crops either of cash crops or fodders crops was calculated from secondary data obtained from the report of irrigated water for Egyptian crops published by Soil, Water and Environmental Research Institute (SWERI, 2014). Feeding patterns, milk yield and milk price for dairy buffaloes in winter and summer were collected in different areas. The feed ingredients were calculated in 
winter and summer seasons then converted to cultivated areas to determine irrigated water required to produce these feed ingredients. Dairy buffalo water efficiency was calculated as following:

Dairy buffalo water efficiency $=$ Av. milk production $\mathrm{X}$ milk price $\ldots . .$. (6)

Required water for feed production

The studied farms were divided into groups according to the feeding packages used. Most farms used corn silage package in winter however, berseem hay, treated straw and molasses were used mainly in summer. Water consumption for rations with/without feeding packages during winter and summer are presented in Annex 1 and 2 . The collected data were statistically analyzed by the least squares technique using the general linear model procedure of SAS program (SAS, 2010). Duncan test (Duncan 1955) was used to locate treatment means that are significantly different. Two factorial arrangements were used $2 \times 3$ and $4 \times 3$; the two analyses were performed through the same statistical model, the first for winter and the second for summer. The following linear model was used in the analysis of quantitative data:

$$
Y_{i j k}=\mu+F_{i}+G_{j}+F G_{i j}+e_{i j k}
$$

Where:-

$\mathrm{Y}_{\mathrm{ijk}}=$ observation $\mathrm{k}=$ number of farms $1,2 \ldots \ldots \ldots . . .50, \mu=$ overall mean, $\mathrm{F}_{\mathrm{i}}=$ the effect of feed pattern $\mathrm{i}^{\text {th }}=1,2$ ( $1=$ Traditional ration (without feeding packages), $2=$ ration with corn silage during winter) and $\mathrm{i}^{\text {th }}=1,2,3$ and 4 ( $1=$ Traditional ration (without feeding packages), $2=$ berseem hay, $3=$ treated straw with urea or ammonia and $4=$ molasses addition during summer), $G_{i}=$ the effect of governorate $\mathrm{j}^{\text {th }}=1,2$ and $3(1=$ Kafer El-sheikh, $2=$ Qena and $3=$ El-Beheira $), \mathrm{FG}_{\mathrm{ij}}=$ the interaction effect due to feed pattern and governorates $\mathrm{ij}^{\text {th }}=(1,2,3 \ldots .6$ during winter $)$ and $\mathrm{ij}^{\text {th }}=(1,2,3 \ldots .12$ during summer $), \mathrm{e}_{\mathrm{ijk}}=$ the residual error.

\section{RESULTS AND DISCUSSION}

The results presented in Table(1) indicated that farmers used feeding package such as corn silage with dairy buffaloes during winter showed significant $(\mathrm{P} \leq 0.05)$ higher animal number and milk yield compared to those fed traditional one. Concerning governorate effect, it was found that El-Beheira had the highest $(\mathrm{P} \leq 0.05)$ value of milk production and buffaloes number compared to the other governorates while Qena Governorate recorded the lowest values $(\mathrm{P} \leq 0.05)$.

Governorates and feed packages interaction indicated that milk production and buffaloes number were significantly $(\mathrm{P} \leq 0.05)$ higher for farmers used corn silage as feeding package in the three governorates compared to those fed their animals traditional ration without corn silage. Moreover, Qena without corn silage package gave the lowest value; this might be attributed to higher ambient temperature in Qena than El-Beheira and Kafer El-SheikhData in table (1) revealed that corn silage in ration might reduces feeding cost and improves milk yield that encourage farmers to purchase more animals.

Khalil and Summor (2006) found that using corn silage improved milk production by $0.91 \mathrm{~kg}$ and decreases total ration cost from L.E. 9.27 to L.E. 8.72/day/ dairy buffalo. The improvement in milk yield might be due to the fact that the concentration of neutral-detergent fiber (NDF) of corn silage ranges from 36 to $50 \%$, and the low concentration is desirable. Corn silages with lower acid-detergent fiber (ADF) values have higher energy content are desirable. The lignin content of corn silage is low and a range from about 2 to $4 \%$, low lignin content is desirable.

The consumption of daily berseem, straw and concentrate feed mixture (CFM) was significantly ( $\mathrm{P} \leq$ 0.001 ) higher for traditional rations (without corn silage) than those fed corn silage as feeding package as shown in Table (2). Regarding the governorate effect, Kafr El-Sheikh recorded the highest significant (P $<0.01)$ value of the different feed ingredients whereas, Qena governorate recorded the lowest one and this was accompanied by low milk production. The significant effect of the interaction for daily feeding pattern from the different components was recognized $(\mathrm{P}<0.01)$. When adding corn silage in ration for the three governorates reduced significantly $(\mathrm{P} \leq 0.001)$ all other ration feed ingredients.

Table (3) demonstrated that buffaloes fed on summer rations with berseem hay, Urea/ammoniated straw and ration supplemented with molasses as feeding package were significantly $(\mathrm{P} \leq 0.05)$ higher in milk production compared to those fed traditional rations. The same trend was detected for number of dairy buffaloes. The explanation for increasing buffaloes numbers which fed ration containing feeding 


\section{Khalil et al.}

packages in summer might refer to reducing the feeding costs so encourage farmers to purchase more animals.

Average number of dairy buffalos in El-Beheira was significantly $(\mathrm{P} \leq 0.05)$ higher than other two governorates. The same significant trend was observed for milk yield. The lowest milk yield was observed in Qena and this might be due to the high ambient temperature there, it is worthy to note that milk marketing in Qena still facing difficulties according to the social customs. In respect of the interaction, as a result of using feeding packages (Berseem hay, urea/ammoniated straw and Molasses) El-Beheira farmers had the highest milk production.

Results in table (4) indicated that using berssem hay, molasses, and ammoniated/urea treated straw in animal's ration during summer period significantly reduced $(P \leq 0.05)$ sorghum, (CFM), and straw quantities compared to traditional ration.

El-Beheira governorate showed the highest significant value of using molasses and urea/ammoniated straw, being 0.16 and $0.85 \mathrm{~kg} /$ animal/day, respectively and the lowest value of rice/wheat straw (3.27 $\mathrm{kg} / \mathrm{animal} / \mathrm{day}$ ) as compared to the other governorates. However, Qena recorded the lowest significant value of molasses, urea/ammoniated straw, and concentrate. Therefore, El-Beheira governorate showed the highest milk production while, Qena showed the lowest as indicated in table (3). Regarding the interaction effect using Berseem hay in ration significantly $(P \leq 0.05)$ reduced concentrate in the three governorates. However, it resulted in an insignificant increase of sorghum in Qena and Behaira while, there was a significant decrease in Kafr El-Sheikh. Molasses, and urea/ammoniated straw in Kafr ElSheikh, Qena, and EL-Beheira resulted in the lowest significant $(P \leq 0.01)$ value of sorghum comparable to traditional ration in the aforementioned governorates. Buffaloes fed ammonia/urea treated straw in all the studied governorates consumed the lowest significant quantity of concentrate.

Shetaewi et al. (2001) reported that Damascus goats fed on berseem hay improved milk yield compared to traditional ration. Ohio State University Extension Department (1995) reported that ammonia treatment $(3 \%)$ of dry forages generally increases the $\mathrm{CP}$ content by about 8 percentage units. Ammoniated straw will contain $12-14 \% \mathrm{CP}$ as compared to $4-6 \%$ for untreated straw. The CP content of ammoniated mature grasses can be increase to $18-20 \%$ compared to the $8-12 \%$ for untreated hay. Dry matter digestibility of straws can be enhanced by 10 to 20 percentage units by ammunition. Improvement of 5 to 10 percentage units in dry matter digestibility of mature grasses usually occurs following ammunition. Ammonia treatment also increases animal consumption of low quality forages. The increase in digestibility coupled with the increase in feed intake results in a substantial increase in consumption of digestible energy by animals fed ammoniated forages as compared to those fed untreated forage.

In general, treated straw by ammonia increases the feeding value from low to medium quality grass hay. In other words, ammoniated straw can provide adequate energy and protein to maintain cattle and sheep under harsh conditions. Dinesh Panday (2010) reported that Urea feeding has several advantageous effects on body weight, growth rate, and higher milk yields, even under adverse conditions. Soliman et al. (2003) found that treated rice straw by ammonia gas improved milk production from 10.51 to 11.61 $\mathrm{kg} / \mathrm{day}$. Khalil and Sammour (2006) showed that the quantity of daily concentrate, green forage after using treated rice straw were reduced by 0.08 and $6.0 \mathrm{~kg}$ respectively while, the consumption of treated rice straw increased by $1.5 \mathrm{~kg}$. However, ration cost reduced by L.E. 0.68 and milk production improved by $0.37 \mathrm{~kg} /$ day for dairy buffaloes.

Adding molasses to dairy rations can potentially increase milk production and fiber digestibility, increase milk fat or milk protein content, increase microbial protein production and decrease milk urea nitrogen (MUN). A recent study by (Jeffery Bewley, 2006) found that adding sugarcane molasses at three percent of dry matter increased dry matter intake, yield of milk protein, increased milk protein percent and non-fat solids and lowered MUN. Feeding higher levels from molasses tended to decrease overall performance. The rapidly digested nature of the sugars in molasses increases the animal's ability to utilize soluble protein increasing microbial growth and maximizing microbial protein production.

Tables (5) shows milk production, water consumption and water efficiency during winter period. Milk production was significantly $(P \leq 0.05)$ improved in EL-Beheira governorate when using either traditional or corn silage rations comparable to Qena and Kafr El-Sheikh. Animals fed ration include corn silage as feeding package resulted in an improvement in milk production, water consumption and water efficiency in all selected governorates and in the overall mean too. The water consumption improvement might be due to the reduction in green forage or concentrate mixture quantity. Moreover the ration balance that happened in winter between corn silage as easy digestible energy source with berseem as good protein source lead to reduce feed quantity and water feed consumption. Swift (2003) found that corn silage provides a palatable and digestible source of energy. 
Khalil and Sammour (2006) indicated that the average milk yield of dairy animals before feeding the rations with corn silage was $7.32 \mathrm{~kg} /$ day $/$ buffalo, it increased to $8.23 \mathrm{~kg} /$ day/ buffalo after given the corn silage in the rations. It was clear that silage in the rations improved milk production by $0.91 \mathrm{~kg} / \mathrm{buffalo}$.

Table (6) shows milk production, water consumption and water efficiency during summer period. There was a remarkable increase in milk production in EL-Beheira governorate for buffaloes fed either traditional or the different feeding packages versus the other governorates. Using the different feeding packages resulted in an obvious improvement in milk production especially in EL-Beheira comparable to traditional ration. The highest value of water consumption was observed in the group that used molasses in feeding their animals. Qena showed a little bit higher water consumption possibly because of the high temperature, the land need more water for crops irrigation. Qena was less water efficient compared to Kafr El-Sheikh and El-Beheira however, El-Beheira was the best in water efficiency.

The less efficiency might be attributed to three reasons, the first: milk price in Kafer El-Sheikh is lower than the other two areas and the second: milk production in Qena was much lower compared to Kafer El-Skeikh and El-Beheira governorates and the third is feeding patterns in the three governorates are different. This might be due to the higher supply of buffalo milk and lower demand in Kafer ELSheikh and El-Beheira local markets. Milk production in El-Beheira was higher $(\mathrm{P} \leq 0.05)$ than that in Qena; however, milk price was a little bit higher in Qena. This could be due to feeding costs or the additional cost of cooling milk tanks needed for transportation of milk between villages and collection centers, also milk supply in market is low.

Concerning the overall mean, feeding packages involves treated straw resulted in a little bit higher value of water efficiency versus the traditional ration. These results might be attributed to milk production improvement in winter than summer, also animals subjected to heat stress in summer.

In summer, animals fed ration containing treated straw as feed package gave the highest milk production (605.82 Liter/animal) as compared to others as shown in table (6). This might be due to increasing $\mathrm{CP}$ content by about 8 percentage units. Dry matter digestibility of straws can be enhanced by 10 to 20 percentage units by ammunition. Ammonia treatment also increases animal consumption of low quality roughage. The increase in digestibility coupled with the increase in feed intake results in a substantial increase in consumption of digestible energy by animals fed ammoniated roughage compared to those fed untreated forage. In this respect, animals fed rations containing molasses showed an improvement in milk yield. However, water efficiency recorded the lowest value. It might be due to the fact that sugarcane produce only $3 \%$ molasses, also one feddan of sugarcane irrigated by more than 9000 $\mathrm{m}^{3}$.

Gawelly and Mohamed (2005) reported that return from animal production per $\mathrm{m}^{3}$ water was LE. 4.82. Khalil and Ahmed (2012) reported that dairy buffalo revenues $/ \mathrm{m}^{3}$ were LE. 3.63, L.E. 3.89 and LE. $5.05 / \mathrm{m}^{3}$ for Kafer El-Skeikh, Qena and El-Beheira, respectively.

\section{CONCLUSION}

It is remarkable to notice an improvement of animal feeding leading to increase in milk production. From the results it could be concluded that buffalo milk production increased and water efficiency improved when using one of innovation feeding packages such conserve green forage as silage or hay, treatment crop residues with ammonia or urea and ration supplemented with molasses. These feeding packages should be encouraged this will reduce competition with human food and improve the farmer livelihood through gaining more profit.

\section{REFERENCE}

Dinesh Panday (2010). Urea as a non-portein nitrogen sources for ruminants. B.Sc. Ag. $2^{\text {nd }}$ year, Revew article Institute of Agriculture and Animal Science (IAAS), Rampur, Chitwan, Nepal.

Duncan, D.B. (1955). Multiple ranges and multiple F test. Biometrics 11: 1.farm animals and animal products. Value of Water Res. Rep. Ser. No. 48. UNESCO.

Gawelly, A.A. and A.A. Mohamed (2005). Estimated water efficiency for Egyptian food safety. The 13th agricultural economicconference. 28-29 September pp. 441- 477. IHE, Delft, the Netherlands. 


\section{Khalil et al.}

Jeffery Bewley, Graduate Research Assistant Purdue University (2006). Molasses in dairy rations, for Progressiv dairyman. Reprinted from March 2006 www.Progressive dairy.com.

Khalil M.A. and H.B. Sammour (2006). Economic of some feeding packages application under mixed production system at El-Beheira governorate. Egyptian journal of animal production. Prod., 43: 325339.

Khalil M.A.I. and A.I.M. Ahmed (2012). Water efficiency under the mixed (crop/livestock) farming system in Egypt: 1. Water efficiency of milking buffalo compared to cash crops. Egyptian J. Anim. Prod., 47:111-121.

Mekonnen, M.M. and A.Y. Hoekstra (2010). The green, blue and grey water footprint of Mengistu Alemayehu, Tilahun Amede, Michael BÖhme and Kurt J. Peters (2012). Increasing Livestock Water Productivity under Rain Fed Mixed Crop/Livestock Farming Scenarios of Sub-Saharan Africa: A Review. Journal of Sustainable Development; Vol. 5, No. 7; 2012 ISSN 1913-9063 E-ISSN 19139071 Published by Canadian Center of Science and Education.

Molden, D. (2007). Water for food water for life. A Comprehensive Assessment of water Management in Agriculture. (Earthscan: London, and the International Water Management Institute: Colombo).

Ohio State University Extension Department of Horticulture and Crop Science 2021 Coffey Road, Columbus, Ohio 43210-1044 (1995). Improving lower quality dry forages by ammoniation.

Peden, D.; G. Tadesse and M. Mammo (2003). Improving the water productivity of livestock: an opportunity for poverty reduction. Proceedings of a Workshop on Integrated Water and Land Management Research and Capacity Building Priorities for Ethiopia held on 2-4 December 2002 (pp.57-65), Addis Ababa, Ethiopia.

SAS (2010). SAS/STAT Users guide Release 9.0 S.A.S. Institute, Inc., Cary, North Carolina, USA.

Shetaewi, M.M.; A.M. Abdel-Samee and E.A. Bakr (2001). Reproductive performance and milk production of Damascus goats fed acacia shrubs or berseem clover hay in North Sinai, Egypt. Trop. Animal health Prod., 33(1):67-79.

SWERI (2014), Water requirement ( $\mathrm{m}^{3} /$ feddan) for crops at the main of Aswan water source, the main of canal water source and field (report). Department of Water Requirement and Field Irrigation; Soil, Water and Environment Research Institute; Agricultural Research Center.

Soliman A.A.M; H.M. El-Shabrawy; M.Rashed; S.A. El-OSaadany and A.M. Abd- Khabeer (2003). Effect of using ammonia treatment and benonite supplement to minimize hazards of aflatoxin of crossbred fFresian lactating cow's milk production. Egyptian J. Nutrition and feed. 6 (special issue): 603-616.

Swift M.L. (2003). Feeding High Corn Silage Diets Abbotsford Veterinary Clinic, Abbotsford,BritishColumbia.farmwest.com/index.cfm?method=library. Show page and library pageid $=157$.

Thornton P.K.; R.L. Kruska; N. Henninger; P.M. Kristjanson; R.S. Reid; F. Atieno; A. Odero and T. Ndegwa (2002). Mapping poverty and livestock in the developing world (p. 124). International Livestock Research Institute, Nairobi, Kenya. 


\title{
تقييم الحزم الغذائية على أساس كفاءة المياه لمزارع الجاموس الحلاب تحت النظام المختلط ( نباتى/حيوانى) فى

\author{
مصطفى عبد الرازق إبراهيم خليل ، آمال صالح عمر ، رضا السيد حموده

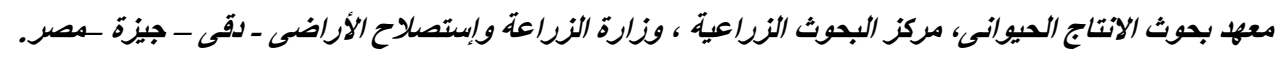

الهدف من الدراسة هو تقدير الكفاءة المائية للجاموس الحلاب بإستخدام إحدي الحزم الغذائية كأحد مكونات العلائق. تمت تمث الدراسة

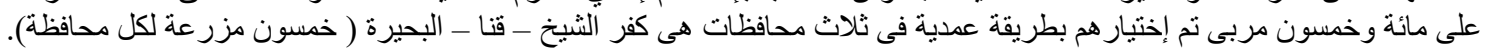

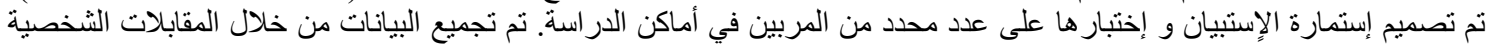

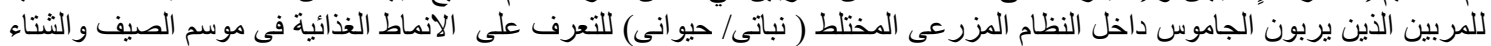

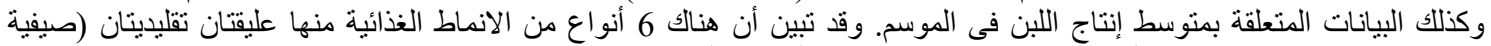

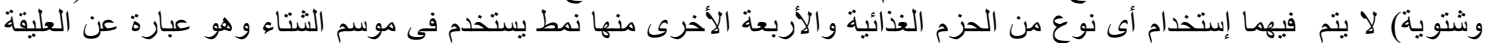

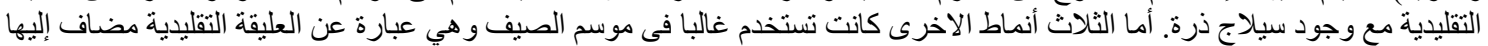

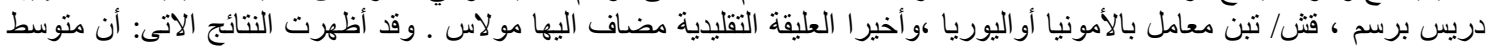
إنتاج اللبن فى موسم الثتاء كان



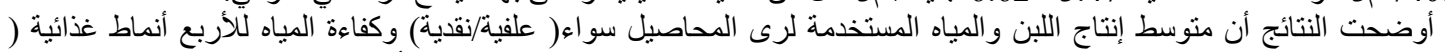

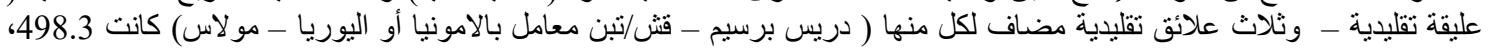

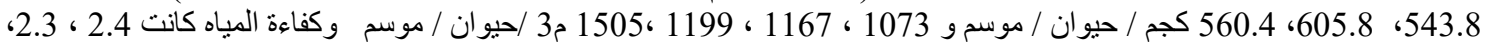

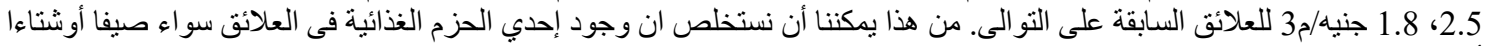
أدي الي تحسن في إنتاج اللبن. 
Table (1). Number of dairy buffalos and milk production (LSM \pm SE) as affected by feed Packages, governorate and their interaction in winter period.

\begin{tabular}{|c|c|c|c|}
\hline \multirow{2}{*}{ Item } & \multirow{2}{*}{ Farmer Number } & \multirow{2}{*}{$\begin{array}{l}\text { Number of } \\
\text { dairy buffaloes }\end{array}$} & \multirow{2}{*}{$\begin{array}{l}\text { Milk Production } \\
\text { (kg/animal) }\end{array}$} \\
\hline & & & \\
\hline \multicolumn{4}{|l|}{ Feed Packages } \\
\hline Traditional & 20 & $2.13^{\mathrm{b}} \pm 0.28$ & $785.86^{\mathrm{b}} \pm 12.59$ \\
\hline Corn silage & 41 & $3.62^{\mathrm{a}} \pm 0.21$ & $1127.88^{\mathrm{a}} \pm 11.55$ \\
\hline $\mathrm{P}$-value & & $* * *$ & $* * *$ \\
\hline \multicolumn{4}{|l|}{ Governorate } \\
\hline Kafr El-Sheikh & 20 & $2.73^{\mathrm{b}} \pm 0.31$ & $946.67^{\mathrm{ab}} \pm 47.73$ \\
\hline Qena & 13 & $2.64^{\mathrm{b}} \pm 0.34$ & $825.78^{b} \pm 51.42$ \\
\hline EL-Beheira & 28 & $3.26^{\mathrm{a}} \pm 0.25$ & $998.17^{\mathrm{a}} \pm 37.40$ \\
\hline P-value & & $* *$ & $* *$ \\
\hline \multicolumn{4}{|l|}{ Interaction } \\
\hline Traditional*Kafr El-Sheikh & 5 & $2.40^{c} \pm 0.55$ & $803.09^{c} \pm 82.68$ \\
\hline Traditional*Qena & 8 & $2.00^{c} \pm 0.50$ & $720.52^{\mathrm{d}} \pm 75.47$ \\
\hline Traditional*EL-Beheira & 7 & $2.00^{c} \pm 0.41$ & $833.97^{\mathrm{c}} \pm 61.62$ \\
\hline Corn silage*Kafr El-Sheikh & 15 & $3.06^{\mathrm{b}} \pm 0.31$ & $1131.03^{\mathrm{ab}} \pm 69.87$ \\
\hline Corn silage*Qena & 5 & $3.28^{\mathrm{ab}} \pm 0.46$ & $990.24^{b} \pm 47.73$ \\
\hline Corn silage*EL-Beheira & 21 & $4.52^{\mathrm{a}} \pm 0.28$ & $1162.36^{\mathrm{a}} \pm 42.41$ \\
\hline P- value & & $* * *$ & $* * *$ \\
\hline
\end{tabular}

Table (2). Daily feeding patterns (LSM \pm SE) for dairy buffalos as affected by feed packages, governorate and their interaction during winter period.

\begin{tabular}{|c|c|c|c|c|}
\hline \multirow{2}{*}{ Item } & Berseem & Concentrate & Rice/wheat Straw & Corn silage \\
\hline & (kg/animal/day) & (kg/animal/d) & (kg/animal/day) & (kg/animal/day) \\
\hline \multicolumn{5}{|l|}{ Feed Packages } \\
\hline Traditional & $56.38^{\mathrm{a}} \pm 2.21$ & $4.32^{\mathrm{a}} \pm 0.15$ & $5.23^{\mathrm{a}} \pm 0.16$ & - \\
\hline Corn silage & $37.74^{\mathrm{b}} \pm 1.64$ & $2.39^{\mathrm{b}} \pm 0.11$ & $2.30^{\mathrm{b}} \pm 0.12$ & $16.03 \pm 0.48$ \\
\hline $\mathrm{P}$-value & $* * *$ & $* * *$ & $* * *$ & $* * *$ \\
\hline \multicolumn{5}{|l|}{ Governorate } \\
\hline Kafr El-Sheikh & $49.58^{\mathrm{a}} \pm 2.48$ & $3.51^{\mathrm{a}} \pm 0.17$ & $4.69^{\mathrm{a}} \pm 0.18$ & $8.90^{\mathrm{a}} \pm 0.73$ \\
\hline Qena & $44.01^{\mathrm{c}} \pm 2.67$ & $3.27^{b} \pm 0.18$ & $3.82^{\mathrm{c}} \pm 0.20$ & $7.85^{\mathrm{c}} \pm 0.79$ \\
\hline EL-Beheira & $47.60^{\mathrm{b}} \pm 1.94$ & $3.29^{\mathrm{ab}} \pm 0.13$ & $4.12^{\mathrm{b}} \pm 0.14$ & $8.00^{\mathrm{b}} \pm 0.57$ \\
\hline P-value & $* *$ & $* *$ & $* *$ & $* *$ \\
\hline \multicolumn{5}{|l|}{ Interaction } \\
\hline Traditional*Kafr El-Sheikh & $60.00^{\mathrm{a}} \pm 4.30$ & $4.60^{\mathrm{a}} \pm 0.30$ & $5.20^{\mathrm{ab}} \pm 0.32$ & - \\
\hline Traditional*Qena & $52.50^{\mathrm{b}} \pm 3.92$ & $4.16^{\mathrm{b}} \pm 0.27$ & $5.16^{b} \pm 0.29$ & - \\
\hline Traditional*EL-Beheira & $56.66^{\mathrm{ab}} \pm 3.20$ & $4.22^{\mathrm{b}} \pm 0.22$ & $5.33^{\mathrm{a}} \pm 0.24$ & - \\
\hline Corn silage*Kafr El-Sheikh & $39.16^{\mathrm{c}} \pm 2.48$ & $2.42^{\mathrm{c}} \pm 0.17$ & $2.19^{\mathrm{d}} \pm 0.18$ & $16.4 \pm 0.73$ \\
\hline Corn silage*Qena & $35.53^{\mathrm{d}} \pm 3.63$ & $2.39^{c} \pm 0.25$ & $2.48^{c} \pm 0.27$ & $15.71 \pm 1.07$ \\
\hline Corn silage*EL-Beheira & $38.53^{\mathrm{c}} \pm 2.20$ & $2.36^{\mathrm{c}} \pm 0.15$ & $2.22^{\mathrm{cd}} \pm 0.16$ & $16.00 \pm 0.65$ \\
\hline P-value & $* * *$ & $* * *$ & $* * *$ & NS \\
\hline
\end{tabular}


Table (3). Number of dairy buffaloes and milk production (LSM \pm SE) as affected by feed packages, governorate and their interaction during summer period.

\begin{tabular}{|c|c|c|c|}
\hline Item & Farmer Number & $\begin{array}{c}\text { dairy buffaloes } \\
\text { number }\end{array}$ & $\begin{array}{c}\text { Milk Production } \\
\text { (Liter /animal) }\end{array}$ \\
\hline \multicolumn{4}{|l|}{ Feed Packages } \\
\hline Traditional & 20 & $1.97^{\mathrm{c}} \pm 0.15$ & $498.31^{\mathrm{c}} \pm 22.87$ \\
\hline Berseem hay & 17 & $2.11^{\mathrm{b}} \pm 0.19$ & $543.77^{\mathrm{bc}} \pm 28.58$ \\
\hline Ammonia/Urea & 15 & $2.44^{\mathrm{a}} \pm 0.16$ & $605.82^{\mathrm{a}} \pm 25.11$ \\
\hline Molasses & 12 & $2.02^{\mathrm{bc}} \pm 0.14$ & $560.41^{\mathrm{b}} \pm 21.42$ \\
\hline P-value & & $* *$ & $* * *$ \\
\hline \multicolumn{4}{|l|}{ Governorate } \\
\hline Kafr El-Sheikh & 19 & $2.04^{\mathrm{b}} \pm 0.13$ & $514.05^{\mathrm{b}} \pm 22.60$ \\
\hline Qena & 24 & $1.95^{\mathrm{c}} \pm 0.13$ & $481.24^{\mathrm{c}} \pm 20.58$ \\
\hline EL-Beheira & 21 & $2.22^{\mathrm{a}} \pm 0.15$ & $660.94^{\mathrm{a}} \pm 20.78$ \\
\hline $\mathrm{P}$ - value & & $* * *$ & $* * *$ \\
\hline \multicolumn{4}{|l|}{ Interaction } \\
\hline Traditional*Kafr El-Sheikh & 5 & $2.00^{\mathrm{cd}} \pm 0.28$ & $481.60^{\mathrm{d}} \pm 42.01$ \\
\hline Traditional*Qena & 9 & $1.16^{\mathrm{d}} \pm 0.25$ & $416.00^{\mathrm{e}} \pm 38.35$ \\
\hline Traditional*EL-Beheira & 6 & $2.00^{\mathrm{cd}} \pm 0.25$ & $597.33^{\mathrm{bc}} \pm 38.35$ \\
\hline Berseem hay*Kafr El-Sheikh & 6 & $2.00^{\mathrm{cd}} \pm 0.36$ & $501.33^{\mathrm{d}} \pm 54.24$ \\
\hline Berseem hay*Qena & 7 & $2.33^{\mathrm{bc}} \pm 0.36$ & $416.00^{\mathrm{e}} \pm 54.24$ \\
\hline Berseem hay*EL-Beheira & 4 & $2.00^{\mathrm{cd}} \pm 0.25$ & $714.00^{\mathrm{a}} \pm 38.35$ \\
\hline Ammonia/Urea*Kafr El-Sheikh & 5 & $2.75^{\mathrm{a}} \pm 0.31$ & $513.00^{\mathrm{d}} \pm 46.97$ \\
\hline Ammonia/Urea*Qena & 3 & $2.57^{\mathrm{b}} \pm 0.23$ & $605.48^{\mathrm{bc}} \pm 35.51$ \\
\hline Ammonia/Urea*EL-Beheira & 7 & $2.00^{\mathrm{cd}} \pm 0.31$ & $699.00^{\mathrm{ab}} \pm 46.97$ \\
\hline Molasses*Kafr El-Sheikh & 3 & $2.14^{\mathrm{c}} \pm 0.23$ & $560.28^{c} \pm 35.51$ \\
\hline Molasses*Qena & 5 & $2.12^{\mathrm{c}} \pm 0.22$ & $487.50^{\mathrm{d}} \pm 33.22$ \\
\hline Molasses*EL-Beheira & 4 & $1.80^{\mathrm{d}} \pm 0.28$ & $633.45^{\mathrm{b}} \pm 42.01$ \\
\hline P- value & & $* *$ & $* * *$ \\
\hline
\end{tabular}


Egyptian J. Nutrition and Feeds (2015), 18(2) Special Issue: 125-136

Table (4). Daily feed patterns (LSM \pm SE) for dairy buffalos as affected by feed packages, governorates and their interaction during summer period

\begin{tabular}{|c|c|c|c|c|c|c|}
\hline \multirow[t]{2}{*}{ Item } & Sorghum & Concentrate & Rice/wheat Straw & Berseem hay & Molasses & $\begin{array}{l}\text { Ammonia/ Urea } \\
\text { treatment }\end{array}$ \\
\hline & (kg/animal/d) & (kg/animal/d) & (kg/animal/d) & (kg/animal/d) & (kg/animal/d) & (kg/animal/d) \\
\hline \multicolumn{7}{|l|}{ Feed Packages } \\
\hline Traditional & $28.11^{\mathrm{a}} \pm 1.92$ & $5.94^{\mathrm{a}} \pm 0.17$ & $4.42^{\mathrm{a}} \pm 0.27$ & - & - & - \\
\hline Berseem hay & $24.94^{\mathrm{b}} \pm 2.40$ & $4.02^{\mathrm{b}} \pm 0.21$ & $3.95^{\mathrm{b}} \pm 0.34$ & $5.77 \pm 0.12$ & - & - \\
\hline Molasses & $22.04^{\mathrm{c}} \pm 2.11$ & $3.36^{\mathrm{c}} \pm 0.18$ & $3.35^{\mathrm{c}} \pm 0.30$ & - & $0.58 \pm 0.01$ & - \\
\hline Ammonia/Urea & $22.54^{\mathrm{c}} \pm 1.80$ & $2.57^{\mathrm{d}} \pm 0.15$ & $3.37^{c} \pm 0.25$ & - & - & $3.70 \pm 0.34$ \\
\hline P-value & $* *$ & $* * *$ & $* *$ & $* * *$ & $* * *$ & $* * *$ \\
\hline \multicolumn{7}{|l|}{ Governorate } \\
\hline Kafr El-Sheikh & $23.51^{\mathrm{b}} \pm 1.90$ & $4.20^{\mathrm{a}} \pm 0.16$ & $4.11^{\mathrm{a}} \pm 0.27$ & $1.38^{\mathrm{b}} \pm 0.09$ & $0.15^{\mathrm{b}} \pm 0.01$ & $0.46^{\mathrm{b}} \pm 0.36$ \\
\hline Qena & $26.59^{\mathrm{a}} \pm 1.73$ & $3.30^{\mathrm{c}} \pm 0.15$ & $4.30^{\mathrm{a}} \pm 0.24$ & $1.62^{\mathrm{a}} \pm 0.08$ & $0.13^{\mathrm{c}} \pm 0.01$ & $0.31^{\mathrm{c}} \pm 0.33$ \\
\hline EL-Beheira & $25.37^{\mathrm{a}} \pm 1.74$ & $3.96^{\mathrm{b}} \pm 0.15$ & $3.27^{\mathrm{b}} \pm 0.24$ & $1.58^{\mathrm{a}} \pm 0.08$ & $0.16^{\mathrm{a}} \pm 0.01$ & $0.85^{\mathrm{a}} \pm 0.33$ \\
\hline P- value & $* *$ & $* *$ & $* *$ & $* *$ & $* *$ & $* * *$ \\
\hline \multicolumn{7}{|l|}{ Interaction } \\
\hline Traditional*Kafr El-Sheikh & $26.00^{\mathrm{bc}} \pm 3.53$ & $6.00^{\mathrm{a}} \pm 0.31$ & $4.54^{\mathrm{ab}} \pm 0.50$ & - & - & - \\
\hline Traditional*Qena & $30.33^{\mathrm{ab}} \pm 3.22$ & $5.83^{\mathrm{ab}} \pm 0.28$ & $4.53^{\mathrm{ab}} \pm 0.45$ & - & - & - \\
\hline Traditional*EL-Beheira & $28.00^{\mathrm{b}} \pm 3.22$ & $6.00^{\mathrm{a}} \pm 0.28$ & $4.20^{\mathrm{b}} \pm 0.45$ & - & - & - \\
\hline Berseem hay*Kafr El-Sheikh & $21.11^{\mathrm{d}} \pm 4.56$ & $5.00^{\mathrm{bc}} \pm 0.40$ & $4.53^{\mathrm{ab}} \pm 0.65$ & $5.33^{\mathrm{b}} \pm 0.23$ & - & - \\
\hline Berseem hay*Qena & $32.22^{\mathrm{a}} \pm 4.56$ & $4.66^{\mathrm{c}} \pm 0.40$ & $4.53^{\mathrm{ab} \pm 0.65}$ & $6.00^{\mathrm{a}} \pm 0.23$ & - & - \\
\hline Berseem hay*EL-Beheira & $30.50^{\mathrm{ab}} \pm 3.22$ & $5.41^{\mathrm{b}} \pm 0.28$ & $4.20^{\mathrm{b}} \pm 0.55$ & $6.00^{\mathrm{a}} \pm 0.16$ & - & - \\
\hline Molasses*Kafr El-Sheikh & $21.81^{\mathrm{d}} \pm 3.95$ & $3.12^{\mathrm{d}} \pm 0.35$ & $3.50^{\mathrm{cd}} \pm 0.56$ & - & $0.55^{\mathrm{b}} \pm 0.03$ & - \\
\hline Molasses*Qena & $21.33^{\mathrm{d}} \pm 2.98$ & $3.71^{\mathrm{cd}} \pm 0.26$ & $4.57^{\mathrm{a}} \pm 0.42$ & - & $0.61^{\mathrm{a}} \pm 0.02$ & - \\
\hline Molasses*EL-Beheira & $23.00^{c} \pm 3.95$ & $3.25^{\mathrm{d}} \pm 0.35$ & $2.00^{\mathrm{e}} \pm 0.56$ & - & $0.60^{\mathrm{ab}} \pm 0.03$ & - \\
\hline Ammonia/Urea*Kafr El-Sheikh & $25.15^{\mathrm{b}} \pm 2.98$ & $2.71^{\mathrm{e}} \pm 0.26$ & $3.87^{\mathrm{c}} \pm 0.42$ & - & - & $5.35^{\mathrm{a}} \pm 0.57$ \\
\hline Ammonia/Urea*Qena & $22.47^{\mathrm{cd}} \pm 2.79$ & $2.62^{\mathrm{e}} \pm 0.24$ & $3.57^{\mathrm{cd}} \pm 0.39$ & - & - & $3.25^{\mathrm{b}} \pm 0.54$ \\
\hline Ammonia/Urea*EL-Beheira & $20.00^{\mathrm{e}} \pm 3.53$ & $2.40^{\mathrm{e}} \pm 0.31$ & $2.68^{\mathrm{d}} \pm 0.50$ & - & - & $2.50^{\mathrm{c}} \pm 0.68$ \\
\hline $\mathrm{P}$-value & $* *$ & $* * *$ & $* *$ & $* * *$ & $* * *$ & $* * *$ \\
\hline
\end{tabular}

a-b-c-d-e values, within a column, with different superscripts differ significantly. $(* *=P<0.01$, and $* * *=P<0.001)$. 
Table (5). Milk production, water consumption and water efficiency in the different governorates with and without feeding package during winter period.

\begin{tabular}{|c|c|c|c|c|}
\hline Item & Kafr El-Sheikh & Qena & EL-Beheira & Overall mean \\
\hline Milk production Traditional & 803.09 & 720.52 & 833.97 & 785.86 \\
\hline Water consumption $\mathrm{M}^{3}$ & 1055 & 984 & 1009 & 1016 \\
\hline Water efficiency* (L.E.)/ $\mathrm{M}^{3}$ & 3.04 & 3.66 & 3.72 & 3.47 \\
\hline Milk production Corn silage & 1131.03 & 990.24 & 1162.36 & 1094.54 \\
\hline Water consumption $\mathrm{M}^{3}$ & 738 & 714 & 770 & 740.67 \\
\hline Water efficiency* (L.E.)/ $\mathrm{M}^{3}$ & 6.13 & 6.93 & 6.79 & 6.62 \\
\hline
\end{tabular}

Table (6). Milk production, water consumption and water efficiency in the different governorates with or without feeding packages during summer period.

\begin{tabular}{|c|c|c|c|c|}
\hline Item & Kafr El-Sheikh & Qena & EL-Beheira & Overall mean \\
\hline Milk production Traditional & 481.6 & 416.00 & 597.33 & 498.3 \\
\hline Water consumption $\mathrm{M}^{3}$ & 1050 & 1210 & 959 & 1073 \\
\hline Water efficiency* (L.E.)/ $\mathrm{M}^{3}$ & 2.29 & 1.72 & 3.11 & 2.4 \\
\hline Milk production Berseem hay hay & 501.33 & 416.00 & 714.00 & 543.8 \\
\hline Water consumption $\mathrm{M}^{3}$ & 1112 & 1215 & 1175 & 1167 \\
\hline Water efficiency* (L.E.)/ $\mathrm{M}^{3}$ & 2.25 & 1.71 & 3.04 & 2.3 \\
\hline Milk production Treated straw & 513.00 & 605.48 & 699.00 & 605.8 \\
\hline Water consumption $\mathrm{M}^{3}$ & 1264 & 1179 & 1154 & 1199 \\
\hline Water efficiency* (L.E.)/ $\mathrm{M}^{3}$ & 2.03 & 2.52 & 3.03 & 2.5 \\
\hline Milk production Molasses & 560.28 & 487.50 & 633.45 & 560.4 \\
\hline Water consumption $\mathrm{M}^{3}$ & 1653 & 1761 & 1342 & 1505 \\
\hline Water efficiency* (L.E.)/ $\mathrm{M}^{3}$ & 1.69 & 1.38 & 2.36 & 1.8 \\
\hline
\end{tabular}

Annex (1). Water quantity $\left(\mathrm{M}^{3}\right)$ required to produce feed (traditional (T) and corn silage (CS)) consumed by dairy buffaloes during winter period.

\begin{tabular}{|c|c|c|c|c|c|}
\hline \multirow[b]{2}{*}{ Item } & \multicolumn{4}{|c|}{ Water consumption for ration component (m3) / animal } & \multirow{2}{*}{$\begin{array}{l}\text { Total water } \\
\text { quantity } \\
\text { (M³/animal) }\end{array}$} \\
\hline & Berseem & Concentrate & Rice/wheat Straw & Corn Silage & \\
\hline \multicolumn{6}{|l|}{ Feed Pakages } \\
\hline Traditional & 150 & 528 & 413 & - & 1091 \\
\hline Corn silage & 65 & 236 & 317 & 168 & 786 \\
\hline \multicolumn{6}{|l|}{ Governorate } \\
\hline Kafr El-Sheikh & 140 & 264 & 155 & 164 & 723 \\
\hline Qena & 132 & 267 & 190 & 152 & 741 \\
\hline EL-Beheira & 137 & 265 & 178 & 183 & 763 \\
\hline \multicolumn{6}{|l|}{ Interaction } \\
\hline Kafr El-Sheikh (T) & 162 & 552 & 341 & - & 1055 \\
\hline Qena ((T) & 144 & 519 & 321 & - & 984 \\
\hline EL-Beheira (T) & 150 & 524 & 335 & - & 1009 \\
\hline Kafr El-Sheikh(CS) & 98 & 291 & 179 & 170 & 738 \\
\hline Qena(CS) & 90 & 298 & 190 & 136 & 714 \\
\hline EL-Beheira(CS) & 92 & 293 & 187 & 198 & 770 \\
\hline
\end{tabular}


Khalil et al.

Annex (2). Water quantity $\left(\mathrm{M}^{3}\right)$ required to produce feed (traditional, berseem hay, ammoniated /urea treated straw, and molasses) consumed by dairy buffaloes during summer period.

\begin{tabular}{|c|c|c|c|c|c|c|c|}
\hline \multirow[t]{2}{*}{ Item } & \multicolumn{6}{|c|}{ Water consumption for ration component (m3) / animal } & \multirow[b]{2}{*}{$\begin{array}{c}\text { Total water } \\
\text { quantity } \\
\left(\mathrm{M}^{3}\right) / \\
\text { animal } \\
\end{array}$} \\
\hline & Sorghum & Concentrate & Straw & $\begin{array}{c}\text { Berssem } \\
\text { Hay } \\
(\text { B H) }\end{array}$ & $\begin{array}{c}\text { Ammonia } \\
\text { or Urea } \\
(\mathrm{A} / \mathrm{U})\end{array}$ & $\begin{array}{c}\text { Molasses } \\
\text { (M) }\end{array}$ & \\
\hline \multicolumn{8}{|l|}{ Feeding package } \\
\hline Traditional (T) & 445 & 450 & 240 & - & - & - & 1135 \\
\hline Berseem hay & 440 & 380 & 210 & 300 & - & - & 1330 \\
\hline Molasses & 400 & 350 & 147 & - & - & 460 & 1357 \\
\hline Ammonia/Urea & 408 & 520 & 151 & - & 360 & - & 1439 \\
\hline \multicolumn{8}{|l|}{ Governorate } \\
\hline Kafr El-Sheikh & 430 & 420 & 230 & 72 & 94 & 55 & 1301 \\
\hline Qena & 452 & 344 & 270 & 84 & 79 & 37 & 1266 \\
\hline EL-Beheira & 442 & 370 & 143 & 81 & 101 & 106 & 1243 \\
\hline \multicolumn{8}{|l|}{ Interaction } \\
\hline Kafr El-Sheikh (T) & 459 & 455 & 136 & - & - & - & 1050 \\
\hline Qena (T) & 648 & 272 & 290 & - & - & - & 1210 \\
\hline El-Behera $(\mathrm{T})$ & 443 & 371 & 145 & - & - & - & 959 \\
\hline Kafr El-Sheikh (B & 268 & 449 & 118 & 277 & - & - & 1112 \\
\hline Qena (B H) & 533 & 410 & 152 & 120 & - & - & 1215 \\
\hline EL-Beheira(B H) & 366 & 390 & 30 & 389 & - & - & 1175 \\
\hline KafrEl-Sheikh (A/ & 459 & 455 & - & - & 350 & - & 1264 \\
\hline Qena (A/ U) & 648 & 272 & - & - & 259 & - & 1179 \\
\hline EL-Beheira (A/ U) & 443 & 371 & - & - & 340 & - & 1154 \\
\hline Kafr El-Sheikh (M) & 397 & 561 & 214 & - & - & 481 & 1653 \\
\hline Qena (M) & 762 & 399 & 163 & - & - & 437 & 1761 \\
\hline EL-Beheira (M) & 379 & 494 & 155 & - & - & 314 & 1342 \\
\hline
\end{tabular}

